\title{
CHEMICAL COMPATIBILITY BETWEEN CLADDING ALLOYS AND ADVANCED FUELS
}

\author{
by
}

D. C. Fee and C. E. Johnson

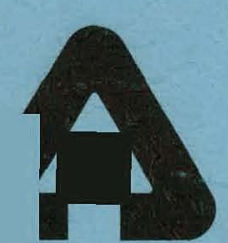

ARGONNE NATIONAL LABORATORY, ARGONNE, ILLINOIS

Prepared for the U. S. ENERGY RESEARCH

AND DEVELOPMENT ADMINISTRATION

under Contract W-31-109-Eng-38 


\section{DISCLAIMER}

This report was prepared as an account of work sponsored by an agency of the United States Government. Neither the United States Government nor any agency Thereof, nor any of their employees, makes any warranty, express or implied, or assumes any legal liability or responsibility for the accuracy, completeness, or usefulness of any information, apparatus, product, or process disclosed, or represents that its use would not infringe privately owned rights. Reference herein to any specific commercial product, process, or service by trade name, trademark, manufacturer, or otherwise does not necessarily constitute or imply its endorsement, recommendation, or favoring by the United States Government or any agency thereof. The views and opinions of authors expressed herein do not necessarily state or reflect those of the United States Government or any agency thereof. 


\section{DISCLAIMER}

Portions of this document may be illegible in electronic image products. Images are produced from the best available original document. 
The facilities of Argonne National Laboratory are owned by the United States Government. Under the terms of a contract (W-31-109-Eng-38) between the U. S. Energy Research and Development Administration, Argonne Universities Association and The University of Chicago, the University employs the staff and operates the Laboratory in accordance with policies and programs formulated, approved and reviewed by the Association.

\section{MEMBERS OF ARGONNE UNIVERSITIES ASSOCIATION}

The University of Arizona

Carnegie-Mellon Univer sity

Case Western Reserve University

The University of Chicago

University of Cincinnati

Illinois Institute of Technulogy

University of Illinois

Indiana University

Iowa State University

The University of Iowa
Kansas State University

The University of Kansas

Loyola University

Marquette Univer sity

Michigan State University

The University of Michigan

University of Minnesota

University of Missouri

Northwestern University

University of Notre Dame
The Ohio State University

Ohio Univer sity

The Pennsylvania State University

Purdue University

Saint Louis University

Southern Illinois University

The University of Texas at Austin

Washington University

Wayne State University

The University of Wisconsin

NOTICE

This report was prepared as an account of work sponsored by the United States Government. Neither the Unitcd States nor the United States Energy Research and Devclopment Administration, nor any of their employees, nor any of their contractors, subcontractors, or their employees, makes any warranty, express or implied, or assumes any legal liability or responsibility for the accuracy, completeness or usefulness of any information, apparatus, product or process disclosed, or represents that its use would not infringe privately-owned rights. Mention of commercial products, their manufacturers, or their suppliers in this publication does not imply or connote approval or disapproval of the product by Argonne National Laboratory or the U. S. Energy Research and Development Administration. 


\section{Argonne National Laboratory \\ 9700 South Cass Avenue \\ Argonne, Illinois 60439}

\section{CHEMICAL COMPATIBILITY BETWEEN CLADDING ALLOYS AND ADVANCED FUELS}

by

D. C. Fee and C. E. Johnson

Chemical Engineering Division

May 1975

This report was prepared as an account of work
sponsored by the United States Government. Neither
the United States nor the United States Fnergy'
Restearch and Vevelopment Administration, nor any of
their employees, nor any of thetr contractors,
subcontractors, or their employees, makes any
Warranty, express or implicd, ur assumes any legal
lability or responsibility for the accuracy, completeness
or usefulness of any information, apparatus, product or
process disclosed, or represents that its use would not
infringe privately owned rights.




\section{THIS PAGE}

\section{WAS INTENTIONALLY \\ LEFT BLANK}




\section{Page}

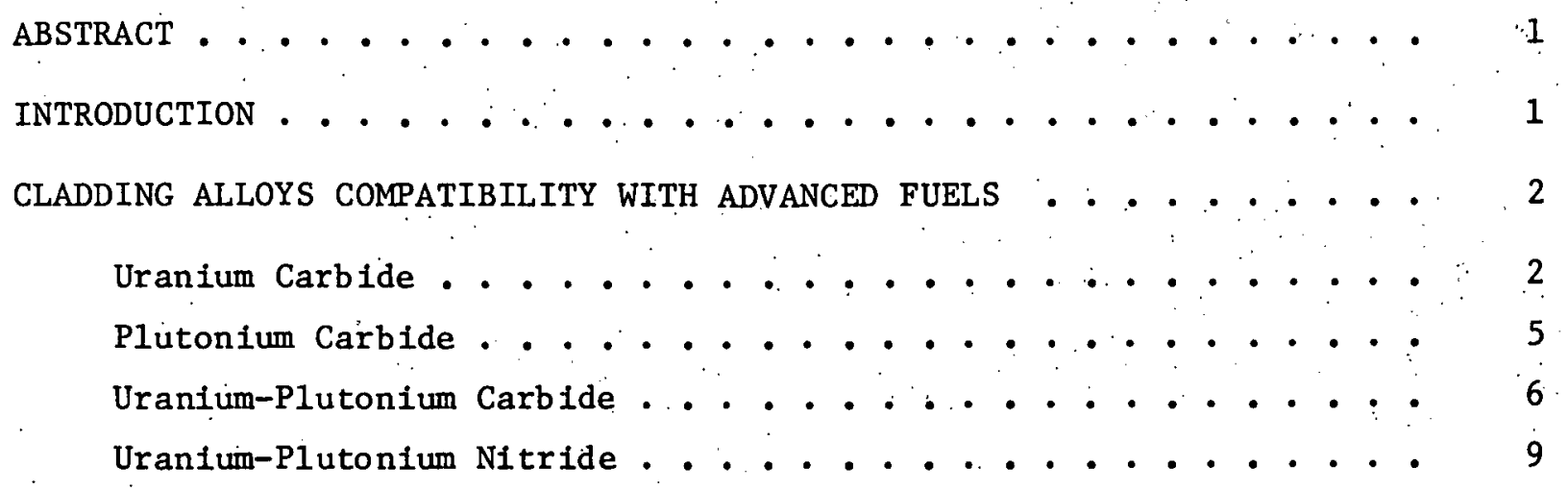

CONCLUSIONS . . . . . . . . . . . . . . . . . . 10

REFERENCES . . . . . . . . . . . . . . . . . . . 11 


\section{LIST OF FIGURES}

No. $\underline{\text { Title }}$

1. Phase Diagram of the Uranium-Carbon System . . . . . . .

2. Comparison of Transfer of Carbon from Uranium Carbide to the : Cladding through Argon and Sodfum Bonding . . . . . . . . 5

3. Phase Diagram of the Plutonium-Carbon System . . . . . . . 6

4. Maximum Depth of Carburization of Sodium-Bonded Uranium-Plutonium Carbide Fuel Elements vs: Equivalent Carbon Content : . . 8

5. Phase Diagrams of B1nary Actinide-Nitrogen Systems. . . . . 9

\section{LIST OF TABLES}

No.

Title

1. Cladding Alloys under Consideration . . . . . . . . . 
CHEMICAL COMPATIBILITY BETWEEN CLADDING ALLOYS AND ADVANCED FUELS

by

D. C. Fee and C. E. Johnson

\begin{abstract}
The National Advanced Fuels Program requires chemical, mechanical, and thermophysical properties data for cladding alloys. The compatibility behavior of cladding alloys with advanced fuels is critically reviewed. In carbide fuel pins, the principal compatibility problem is cladding carburization, diffusion of carbon into the cladding matrix accompanied by carbide precipitation. Carburization changes the mechanical properties of the cladding alloy. The extent of carburization increases in sodium (versus gas) bonded fuels. The depth of carburization increases with increasing sesquicarbide $\left(\mathrm{M}_{2} \mathrm{C}_{3}\right)$ content of. the fuel. In nitride fuel pins, the principal. compatibility problem is cladding nitriding, diffusion of nitrogen into the cladding matrix accompanied by nitride precipitation. Nitriding changes the mechanical properties of the cladding alloy. In both carbide and nitride fuel pins, fission products do not migrate appreciably to the cladding and do not appear to contribute to cladding attack.
\end{abstract}

\title{
INTRODUCTION
}

The Advanced Fuels Program has as one of its major goals the review and evaluation of chemical, mechanical, and thermophysical properties data of potential fast reactor fuel candidates. Initial effort in this program led to the issuance of report ANL/CEN/AF-100, a detailed bibliography of properties data on carbides, nitrides, carbonitrides, oxycarbides, and oxynitrides of uranium and plutonium and mixed uranium-plutonium compounds: This effort continued with the issuance of ANL-AFP-2, an interim report on recommended values for equation of state for advanced fuels, and ANL-AFP-3, an interim report on recommended values for thermal conductivity for advanced fuels. This present report will endeavor to review the compatibility behavior of cladding alloys with advanced fuels. 


\section{CLADDING ALLOYS COMPATIBILITY WITH ADVANCED FUELS}

The chemical compatibility between fuel and cladding can be one of the main life-limiting factors of a fast reactor fuel pin. The formation of new phases at the fuel-cladding interface or other changes in the alloy chemistry of the cladding material can significantly affect the load-bearing capacity of the cladding. In addition, a detailed understanding of the changes that occur near the fuel-cladding interface can be used as a guide in the selection of cladding materials. The cladding materials included in this assessment are given in Table 1.

\section{Uranium Carbide}

Uranium carbide-cladding compatibility problems arise mainly from the narrow homogenefty range of single-phase (stolchiometr1c) UC below $1000^{\circ} \mathrm{C} .1,2$ This 1s shown in Fig. 1. A slight change in the $\mathrm{C} / \mathrm{U}$ ratio leads into. adjacent two-phase regions, $U+U C$ and $U C+U_{2} C_{3}$. Hypostoichiometric uranium carbide, containing free uranium metal, is excluded from consideration as a fuel because of possible eutectic reaction with components of the cladding. These reactions mainly lead to the formation of intermetallic compounds of the $\mathrm{UFe}_{2}$ and $\mathrm{UNi}_{5}$ type. ${ }^{4-8}$ Hyperstolchiometric uranium carbide, containing the less stable sesquicarbide phase $\left(\mathrm{U}_{2} \mathrm{C}_{3}\right)$, leads to greater carburization of the cladding. 1,2,7,9 Carburization of the cladding involves transfer of carbon from the fuel to the cladding and diffusion of carbon in the austenite matrix accompanied by carbide precipitation ${ }^{10}$ according to the general formula $8,11,12$

$$
\mathrm{UC}+(\mathrm{Fe}, \mathrm{Ni}, \mathrm{Cr}) \rightarrow \mathrm{UFe}_{2}+(\mathrm{Fe}, \mathrm{Cr})_{2}{ }_{3} \mathrm{C}_{6}
$$

The cladding becomes too brittle for use when the carbon content exceeds 0.6 wt $\% .^{2}$

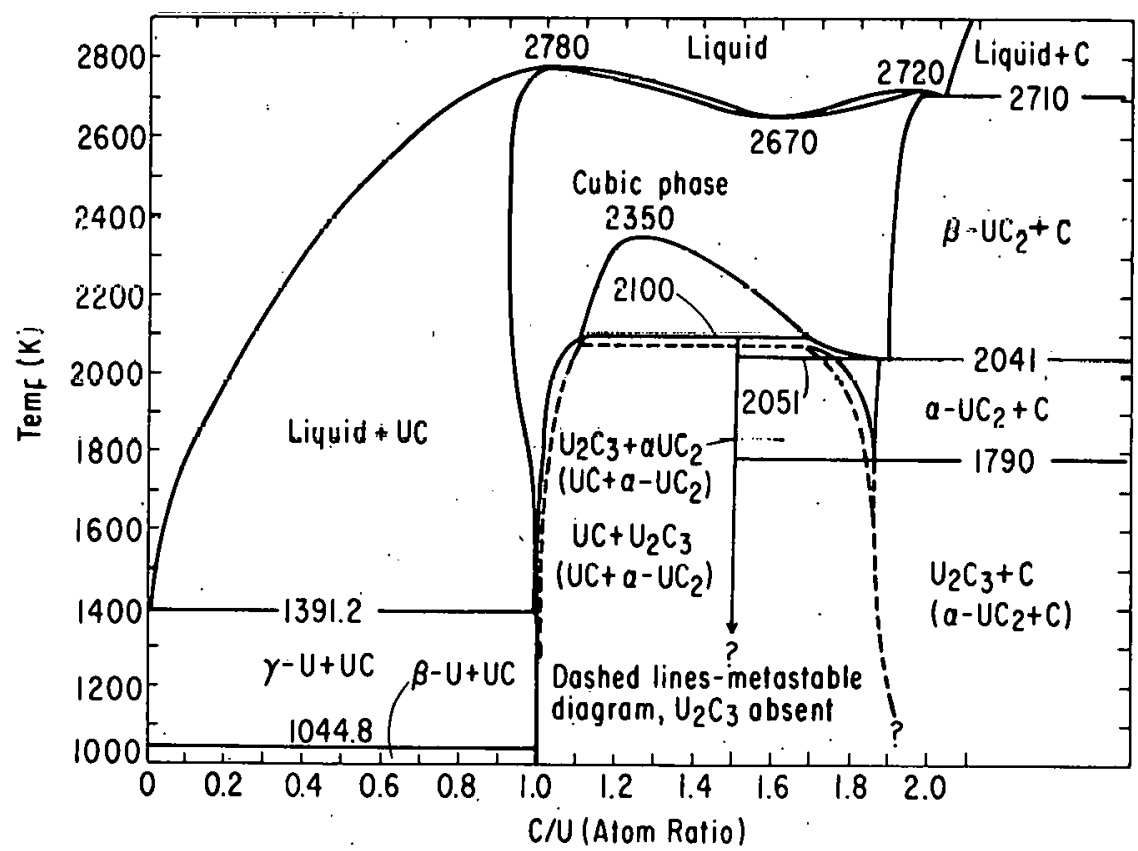

Fig. 1. Phase Diagram of the Uranium-Carbon System ${ }^{3}$ 
TABLE 1. Cladding Alloys under Consideration ${ }^{a}$

\begin{tabular}{|c|c|c|c|c|c|c|c|c|c|c|c|c|}
\hline \multirow[b]{2}{*}{. } & \multicolumn{12}{|c|}{ Composition, \% by Weight } \\
\hline & $\mathrm{Fe}$ & $\mathrm{Ni}$ & $\mathrm{Cr}$ & $\mathrm{C}$ & A1 & $\mathrm{Ti}$ & Mn & Si & $\mathrm{Nb}$ & Mo & $\mathrm{W}$ & other \\
\hline $316 \mathrm{SS}$ & 65 & 12 & 17 & 0.08 & & & 2.0 & 1.0 & & $2-3$ & & \\
\hline $330 \mathrm{sS}$ & 43 & 35 & 19 & 0.05 & & & 1.5 & 1.25 & & & & \\
\hline A286 & 53 & 26 & 15 & 0.05 & 0.2 & $2.1^{\circ}$ & 1.4 & 0.4 & & $1-1.75$ & & 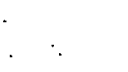 \\
\hline M813 & 39 & 35 & 18 & 0.08 & 1.4 & 2.25 & & & . & 4.0 & & \\
\hline $\mathrm{PE}-16$ & 43 & 35.5 & 16 & 0.1 & 1.2 & 1.2 & & & & 3.0 & . & \\
\hline INCONEL 706 & 40 & 41.5 & 16 & 0.03 & 0.2 & 1.75 & 0.18 & 0.18 & 2.9 & & & \\
\hline INCOLOY 901 & 45 & 42.5 & 12.5 & 0.05 & 0.2 & 2.8 & 0.45 & 0.4 & & 5.7 & & \\
\hline INCONEL 718 & 18.5 & 52.5 & 19 & 0.04 & 0.5 & 0.9 & 0.18 & 0.18 & 5.0 & 3.0 & & \\
\hline $\mathrm{HT}-9$ & 8.5 .5 & 0.5 & 12 & 0.20 & & & & & & 1.0 & 0.5 & $0.3 \mathrm{~V}$ \\
\hline
\end{tabular}

${ }^{a}$ For a discussion of the criteria for the selection of cladding alloys, see S. D. Harkness,

R. Carlander, and P. R. Okamoto, ANL/MSD-06 (1973). 
Attempts have been made to stabilize single-phase uranium carbide by the addition of buffers. The ideal buffering agent forms a carbide that is more stable than $\mathrm{U}_{2} \mathrm{C}_{3}$ but is less stable than UC. Thus, the buffer acts as a carbon-atom acceptor from $\mathrm{U}_{2} \mathrm{C}_{3}$ and a carbon-atom donor to free uranium metal. In both cases, $\mathrm{UC}$ is formed and the second phase, $\mathrm{U}_{2} \mathrm{C}_{3}$ or free uranium metal, is minimized or eliminated. The compounds used as buffers are $\mathrm{W}-\mathrm{UWC}_{2}, 13,14 . \mathrm{V}-\mathrm{UVC}_{2}, 8,15,16 \mathrm{Mo}_{\mathrm{UMOC}}, \mathrm{U}_{2} \mathrm{Cr}-\mathrm{Cr}_{23} \mathrm{C}_{6}, 8,15-18 \mathrm{Fe}-\mathrm{UFe}_{2}, 17,18$ and TI-TiC.12,19 Although buffers offer the advantage of stabilizing singlephase uranium carbide, the use of a buffer creates serfous problems. The effect of the buffer on the thermophysical properties and the irradiation behavior of UC (melting point, swelling rate, etc.) and the interactions between buffer and fission products have yet been sufficiently defined.

Carburization of cladding alloys is the principal problem in the use of hyperstoichiometric UC fuel.1,2,20-22 Fission products do not migrate appreclably to the cladding and do not particlpate in cladding attack.16,20,21 The extent of carburization depends on temperature, carbon activity, and type of bonding agent (gas or sodium).

Temperature. Above $900^{\circ} \mathrm{C}$, carburization proceeds at an extremely rapid rate with type 316 stainless steel. ${ }^{21}$ Acceptable carburization levels are observed below $900^{\circ} \mathrm{C}$.

Carbon Activity. The rate of carburization increases with increasing carbon activity (increasing carbon content) of the uranium carbide. This is shown in Fig. 2. The depth and degree of carburization can be predicted from the carbon concentration and the carbon activity at the interior surface of the cladding. 24 The carbon activity of uranium carbide fuel is unchanged by the inclusion of fission products. $16,25,26$ Thus, the carbon activity in irradiated UC fuel depends on the $\mathrm{C} / \mathrm{U}$ ratio. ${ }^{27}$ The variation of the $\mathrm{C} / \mathrm{U}$ ratio as a function of burnup may be calculated $25,28,29$ if the stoichiometries of the fission product carbides and intermetallic compounds are known. The stoichiometries can be predicted from phase equilibrium and thermodynamic data. Calculation of the $\mathrm{C} / \mathrm{U}$ ratio during burnup will be discussed in the review of Phase Equilibria in Advanced Fuel Systems (ANL-AFP-10). This straight-forward approach to determining the extent of carburization may be changed by two factors:

(1) The possibility of radial redistribution of carbon within the fuel rod during burnup. Carbon transfer to the cooler outer regions of the fuel rod-cladding interface via $\mathrm{CO}_{2} \mathrm{CO}_{2}{ }^{2}, 21$ and $\mathrm{H}_{2} / \mathrm{CH}_{4}$ mechanisms ${ }^{22}$ has been proposed. Carbon transfer to the outer regions of the fuel rod would result in a higher carbon activity at the interior surface of the cladding than the carbon activity calculated from the variation of the $\mathrm{C} / \mathrm{U}$ ratio during burnup. Experimental data to confirm or refute a carbon transfer process are lacking.

(2) The effect of oxygen impurity. The carbon activity is strongly affected by the presence of oxygen impurity in the UC lattice. For example, the carbon activity is decreased by two orders of magnitude when the oxygen content is increased from 150 to roughly $2000 \mathrm{ppm} .30,31$ The carbon activity for varying levels of oxygen impurity can be determined for various $\mathrm{C} / \mathrm{U}$ ratios. Hence, if the initial oxygen level is known, the effect of the oxygen may be incorporated into the calculation of the carbon activity from the variation of the $\mathrm{C} / \mathrm{U}$ ratio during burnup. This approach assumes, of course, that any redistribution of oxygen during burnup is known and taken into account. 


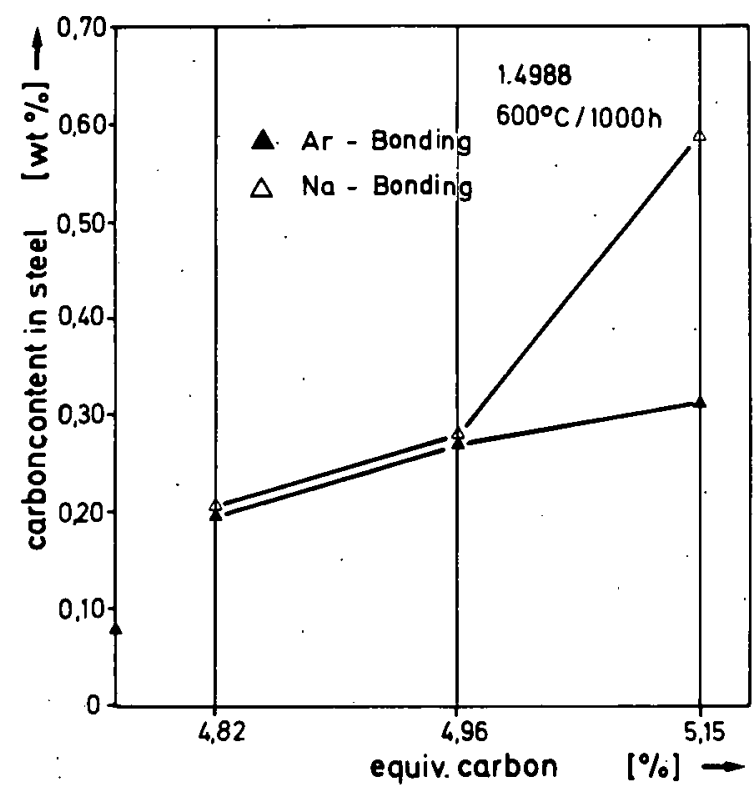

Fig. 2. Comparison of Transfer of Carbon from Uranium Carbide to the Cladding through Argon and Sodium Bonding ${ }^{23}$

Bonding. In all cases, carburization is increased with the use of sodium as a bonding agent. $2,7,20,32,33$ This is shown in Fig. 2. The increased carburization results from the more rapld transfer of carbon to the cladding via the sodium in the annular space between the fuel and cladding. With sodium bonding, diffusion of carbon in the austenite matrix is the rate-limiting step in carburization. In the absence of a sodium bond, transfer of carbon to the cladding is the rate-limiting step. ${ }^{24}$ While the extent of carburization varies dramatically with type of bond, there is no discernible difference in compatibility behavior between type 316 and type 304 stainless steel. (Type 304 stainless steel is no longer a candidate cladding alloy.) However, of the cladding alloys shown in Table 1, compatibility studies have been undertaken only with type 316 stainless steel.

\section{Plutonium Carbide}

By analogy to uranium carbide, problems of plutonium carbide-cladding compatibility are expected to arise mainly from the narrow homogeneity range of single-phase (stolchlometr1c) PuC. This is shown in Fig. 3. A slight change in the $\mathrm{C} / \mathrm{Pu}$ ratio leads into adjacent two-phase regions, $\mathrm{Pu}+\mathrm{PuC}$ and $\mathrm{PuC}+\mathrm{Pu}_{2} \mathrm{C}_{3}$. Hypostoichiometric plutonium carbide is excluded from consideration as a fuel because of possible eutectic reaction with components of the cladding. Hyperstoichiometric plutonium carbide, containing the less stable sesquicarbide phase, $\left(\mathrm{Pu}_{2} \mathrm{C}_{3}\right)$, leads to greater carburization of the cladding. Carburization of the cladding involves transfer of carbon from the fuel to the cladding and diffusion of carbon in the austenitic matrix accompanied by carbide precipitation. 10 The cladding hecomes too brittle for use when the carbon content exceeds $0.6 \mathrm{wt} \% .^{2}$ The limited compatibility data accumulated to date indicate that carburization is the principal compatibility problem. 35 


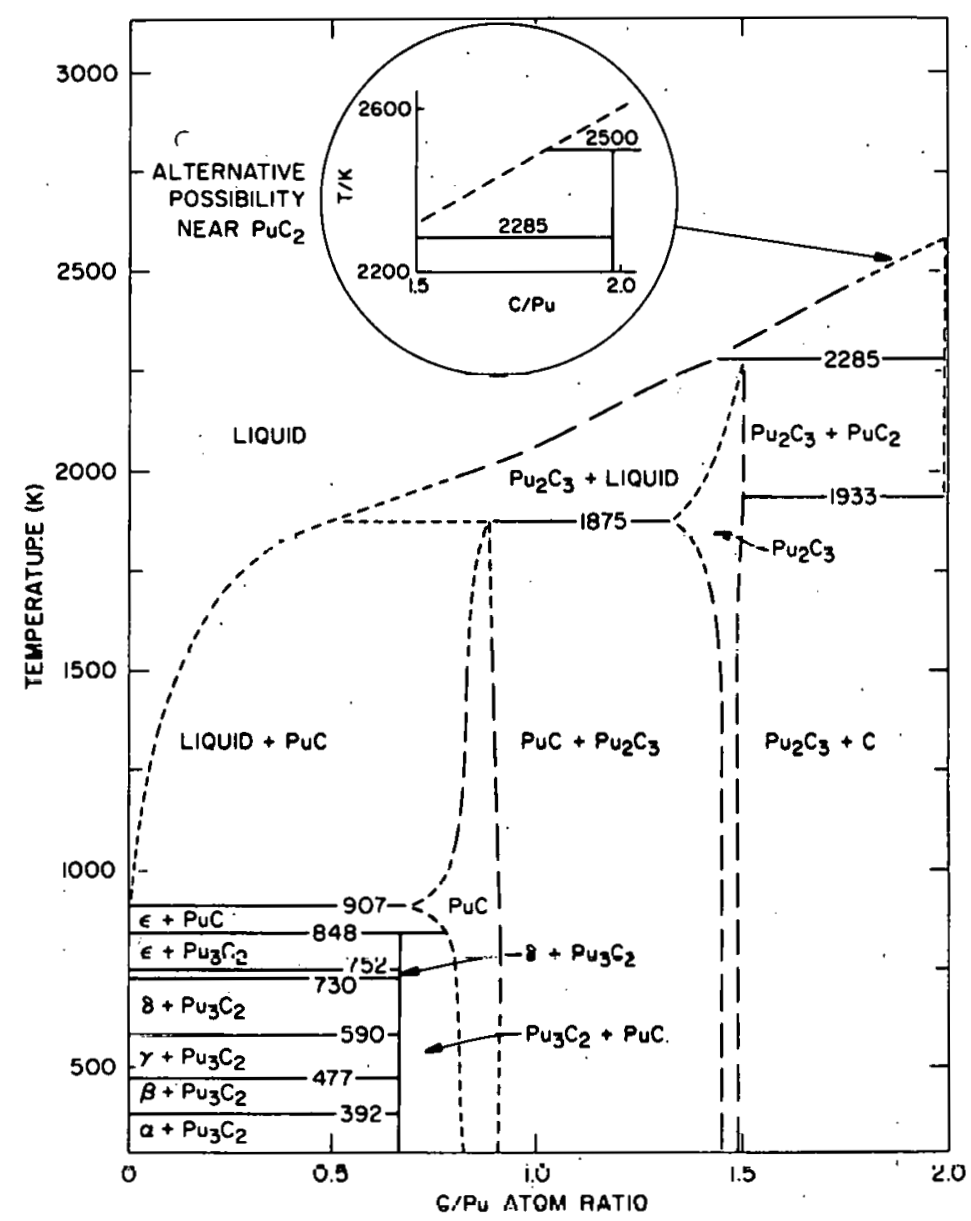

Fig. 3. Phasc Diagram of the PlutoniumCarbon System ${ }^{34}$

\section{Uranium-Plutonium Carbide}

Uranium-plutonium carbide-cladding compatibility problems arise mainly from the narrow homogeneity range of single phase (stoichiometric) $\left(\mathrm{IT}, \mathrm{P}_{11}\right) \mathrm{C}, 2,35-38$ This may be cecn from an examination of the phase diagrams of UC (Fig. 1) and PuC (Fig. 3), which may be used to elicit information on the expected properties of the analogous pseudobinary ( $\mathrm{U}, \mathrm{Pu}) \mathrm{C}$ system. A slight change in the $C / M(M=U+P u)$ ratio leads into adjacent two-phase regions $M+M C$ and $M C+M_{2} C_{3}$. Hypostoichiometric mixed (uranium and plutonium) carbide, contalning free uranium and plutonium metal, is excluded from consideration as a fuel because of possible eutectic reactions with components of the cladding. ${ }^{9}, 9$ These reactions mainly lead to formation of intermetallic compounds of the $(\mathrm{U}, \mathrm{Pu}) \mathrm{Fe}_{2}$ and $(\mathrm{U}, \mathrm{Pu}) \mathrm{Ni}_{5}$ type. Hyperstoichiometric mixed carbide, containing the less stable sesquicarbide phase $\left(\mathrm{M}_{2} \mathrm{C}_{3}\right)$, leads to greater carburization of the cladding. $9,39-41$ Carburization of the cladding involves transfer of carbon from the fuel to the cladding and diffusion of carbon. in the austenite matrix accompanied by carbide precipita$\operatorname{tion}^{10}$ according to the general formulal2

$$
(\mathrm{U}, \mathrm{Pu}) \mathrm{C}+(\mathrm{Fe}, \mathrm{Ni}, \mathrm{Cr}) \rightarrow(\mathrm{U}, \mathrm{Pu}) \mathrm{Fe}_{2}+(\mathrm{Fe}, \mathrm{Cr})_{23} \mathrm{C}_{6}
$$

The cladding becomes too brittle for use when the carbon content exceeds 0.6 wt $\%{ }^{2}$ 
Attempts have been made to stabilize the single-phase mixed carbide by the addition of buffers. The ideal buffering agent forms a carbide that is more stable than $\mathrm{M}_{2} \mathrm{C}_{3}$ but is less stable than MC. Thus, the buffer acts as a carbon-atom acceptor in the case of $\mathrm{M}_{2} \mathrm{C}_{3}$ and a carbon-atom donor in the case of free uranium and plutonium metal. In both cases, $M C$ is formed and the second phase, $\mathrm{M}_{2} \mathrm{C}_{3}$ or free metal, is minimized or eliminated. The compounds used as buffers are $\mathrm{W}-(\mathrm{U}, \mathrm{Pu}) \mathrm{WC}_{2},{ }^{14} \mathrm{Fe}-(\mathrm{U}, \mathrm{Pu}) \mathrm{Fe}_{2}, 42,43 \mathrm{Cr}-\mathrm{Cr}_{23} \mathrm{C}_{6}, 42,43$ Mo-(U, Pu) MoC 2,12 and Ti-TiC. 12,19 Although buffers offer the advantage of stabilizing single-phase mixed carbide, the use of a buffer creates serious problems. The effect of the buffer of the thermophysical properties and the irradiation behavior (melting point, swelling rate, etc.) of the mixed carbide and the interaction between buffer and fission products have not yet been sufficiently defined.

Carburization of the cladding is the principal problem in hyperstoichiometric mixed carbide fuel observed during in-pile $35,44-50$ and out-ofpile $9,22,39,41,51-57$ tests. No redistribution of uranium or plutonium occurs during irradiation. Fission products do not migrate appreciably to the cladding and do not participate in cladding attack.44,48,50 The extent of carburization depends on temperature, carbon activity, and type of bond (helium or sodium).

Temperature. Above $900^{\circ} \mathrm{C}$, carburization proceeds at an extremely rapid rate with type 316 stainless steel. ${ }^{12}$ Similarly, an upper operational limit of $750^{\circ} \mathrm{C}$ has been determined for NIMONIC PE-16.45 other than this, there is no discernible difference in compatibility behavior between type 316 stainless steel and NIMONIC PE-16. Acceptable carburization levels are observed below these temperatures. However, of the cladding alloys shown in Table 1, compatibility studies have been undertaken only with type 316 stainless steel and NIMONIC PE-16.

Carbon Activity. The rate of carburization increases with increasing carbon activity. This is shown in Fig. 4 for mixed carbide fuel pins with approximately 5\% burnup. The depth and degree of carburization can be predicted from the carbon concentration and the carbon activity at the interior surface of the cladding. ${ }^{24}$ The carbon activity of uranium carbide fuel is unchanged by the inclusion of fission products.16,25,26 Thus, the carbon activity in irradiated UC fuel depends on the C/U ratio. ${ }^{27}$ Similar results are expected (but not yet experimentally determined) in mixed carbide fuels; that is, the carbon activity in irradiated mixed carbide $f$ uel should depend only on the $C / M$ ratio. The variation of the $C / M$ ratio as a function of burnup may be calculated $25,28,29$ if the stoichiometries of the fission-product and intermetallic compounds are known. The stoichiometries can be predicted from phase equilibrium and thermodynamic data. Calculation of the $\mathrm{C} / \mathrm{M}$ ratio during burnup will be discussed in the review of Yhase Equilibria in Advanced Fuel Systems (ANL-AFP-10). Th1s stra1ghtforward approach to determining the extent of carburization may be changed by two factors.

(1) The possibility of radial redistribution of carbon within the fuel rod during burnup. As in the case of uranium carbide, carbon transfer to the cooler outer regions of the fuel rod and to the fuel cladding interface has been proposed via $\mathrm{CO} / \mathrm{CO}_{2}{ }^{2}, 21$ and $\mathrm{H}_{2} / \mathrm{CH}_{4}$ mechanisms.22,52 Carbon transfer 


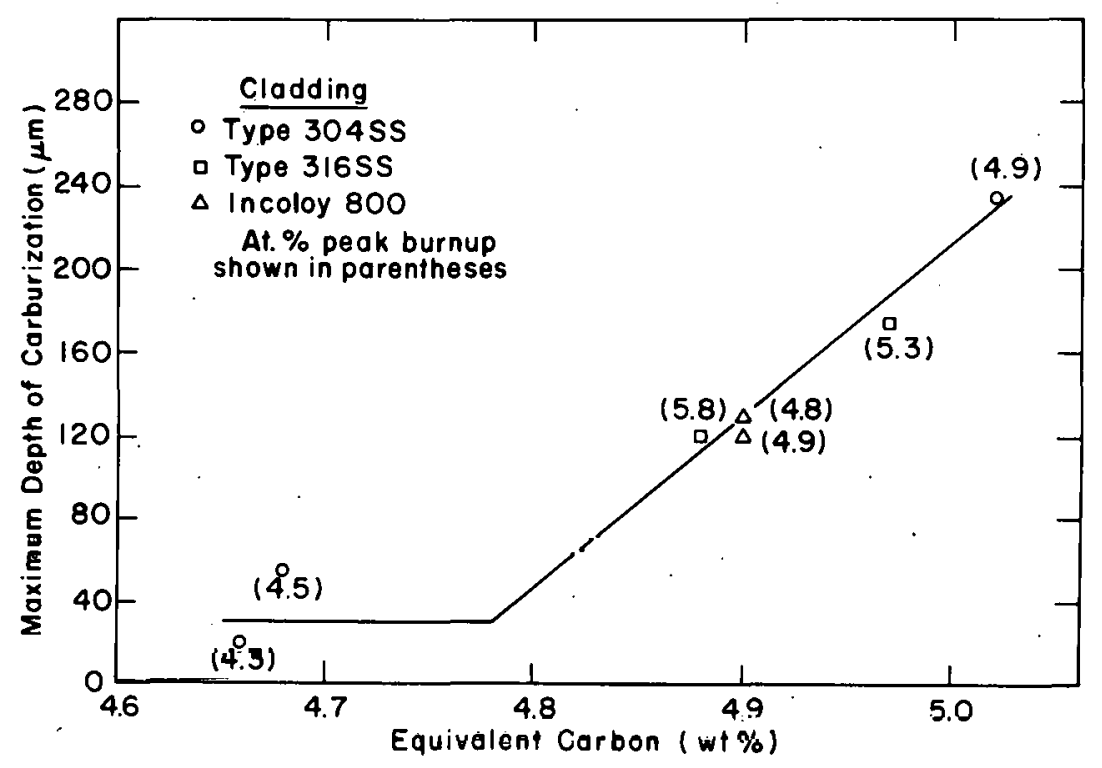

Fig. 4. Maximum Depth of Carburization of Sodium-Bonded Uranium-Plutonium Carbide Fuel Elements vs. Equivalent Carbon Content ${ }^{58}$

to the cooler regions of the fuel rod would lead to an increased carbon activity at the inner surface of the cladding. The carbon activity calculated solely on the basis of the variation of $\mathrm{C} / \mathrm{M}$ ratio during burnup (that is, without taking into account carbon transport to the cladding) would be too low. Experimental data to confirm or refute a carbon transfer process is lacking.

(2) The effect of oxygen impurity. Oxygen impurity would affect the estimation of the extent of carburization in much the same way as has been noted in the case of uranium carbide. Although no experimental data on the effect of oxygen on carbon activity are available for the mixed carbide fuel, the effect is expected to approximate that found in the case of uranium carbide, where an increase from 150 to $\sim 2000 \mathrm{ppm}$ oxygen was found to decrease the carbon activity by two orders of magnitude. 30,31 The carbon activity of the mixed carbide with varying levels of oxygen can be determined for various $C / M$ ratios. Hence. if the initial oxygen level is known, the effect of oxygen may be incorporated into the calculation of carbon activity from the variation of the $C / M$ ratio duxing burnup. This approach assumes, of course, that any redistribution of oxygen during burnup is known and taken into account. In view of the predicted effect of oxygen, it is surprising that out-of-pile compatibility. tests show no effect on the carburization of type 316 stainless steel when the oxygen content of the mixed carbide varied between 900-3700 ppm. 39

Bonding. As in the case of uranium carbide, the more rapid transfer of carbon to the cladding that results from the use of sodium as a bonding agent increases the rate of carburization. 38,52 With sodium bonding, diffusion of carbon in the austenite matrix is the rate-limiting step in carburization. In the absence of a sodium bond, transfer of carbon is the 
rate-limiting step. 24 Sodium-bonded fuel rods exhibit a higher failure rate than helium-bonded fuel rods. ${ }^{59}$ However, this higher failure rate has been attributed to fuel-cladding mechanical interactions rather than increased carburization.

Uranlum-Plutonium N1tride

Problems of compatibility between nitride fuels and cladding arise mainly from the narrow homogeneity range of $U N$ and PuN in a manner that is analogous to carbide fuels. Figure 5 indicates that a slight change in the $\mathrm{N} / \mathrm{U}$ (or $\mathrm{N} / \mathrm{Pu}$ ) ratio leads into adjacent two phase regions $U+U N$ $(\mathrm{Pu}+\mathrm{PuN})$ or $\mathrm{UN}+\mathrm{U}_{2} \mathrm{~N}_{3}\left(\mathrm{PuN}+\mathrm{N}_{2}\right)$. Studies with $\mathrm{UN}, 61 \mathrm{PuN}, 62$ and mixed nitrides $63-67$ show that hypostolchlometric fuel, containing the free metal, is excluded from consideration as a fuel because of possible eutectic reactions with components of the cladding. These reactions mainly lead to intermetallic compounds of the $(\mathrm{U}, \mathrm{Pu}) \mathrm{Fe}_{2}$ and (U, $\left.\mathrm{Pu}\right) \mathrm{N}_{5}$ type. Studies with UN $64,66,68,69$ and mixed nitrides 64,67 show that hyperstoichiometric fuel, containing the less stable sesquinitride phase $\left(\mathrm{U}_{2} \mathrm{~N}_{3}\right)$, leads to greater nitriding of the cladding. Nitriding of the cladding involves diffusion of nitrogen in the austenite matrix accompanied by nitride precipitation according to the general formula $66,68,69$

$$
\mathrm{U}_{2} \mathrm{~N}_{3}+2 \mathrm{Cr} \rightarrow \mathrm{Cr}_{2} \mathrm{~N}+2 \mathrm{UN}
$$

The consequence of nitriding the cladding is that the strength of the cladding is increased while the ductility is decreased.
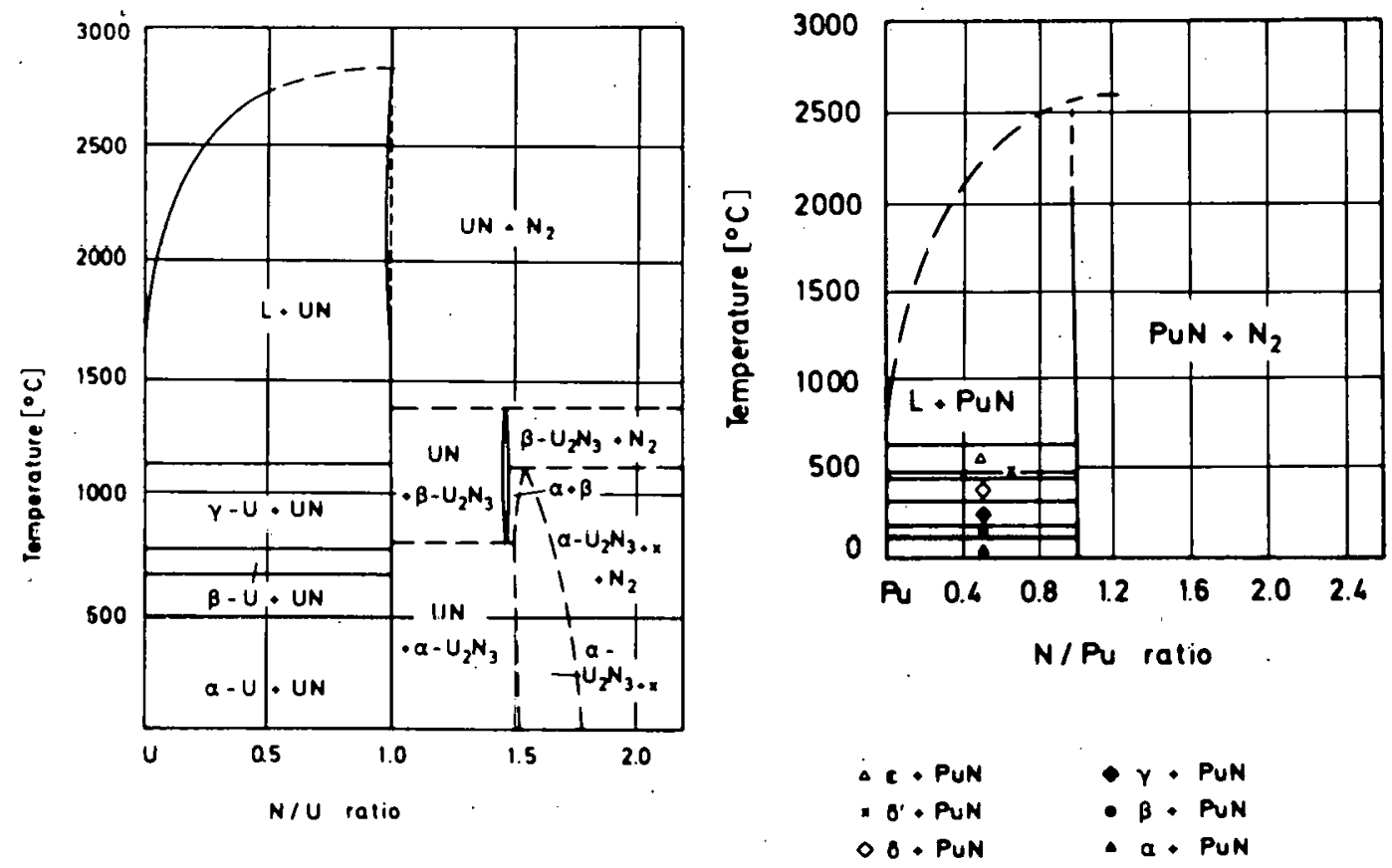

Fig. 5. Phase Diagrams of Binary Actinide-Nitrogen Systems ${ }^{60}$ 
Nitriding the cladding is the principal problem in hyperstoichiometric $\mathrm{UN}, 61,63,66,68-75 \mathrm{PuN}, 61-63,66,69$ and (U,Pu)N.63,65-67,74,76 In-pile studies of $\mathrm{UN}^{61,75}$ and $(\mathrm{U}, \mathrm{Pu}) \mathrm{N}^{6 \cdot 1}, 65,67,76$ show that fission products do not migrate appreciably to the cladding and do not participate in cladding attack. There is, in general, no redistribution of uranium and plutonium in irradiated fuel. However, plutonium redistribution in ( $\mathrm{U}, \mathrm{Pu}) \mathrm{N}$ during thermal irradiation has been reported.61 Out-of-pile studies show no large temperature dependence of nitriding in tests up to $1000^{\circ} \mathrm{C}$. Acceptable levels of nitriding were observed below this temperature. No cladding alloy has yet been rejected solely on the basis of compatibility behavior. However, of the cladding alloys shown in Table 1, compatibility studies have been undertaken only with type 316 stainless steel and NIMONIC PE-16.69 In general, no difference in nitriding is observed between helium $v s$. sodium bonding. 63-65,67,74,76 However, increased nitriding with a sodium bond has been reported. 66

Oxygen affects compatibility studies in two ways: (1) In out-of-pile tests, an oxide layer has been observed on the surface of $\mathrm{UN}^{66,68,71}$ and $(\mathrm{U}, \mathrm{Pu}) \mathrm{N} .64-66,68$ Oxygen (apparently from the metal surface of the compatibility test capsule) reacted with stolchiometric UN and (U,Pu) N to form the more stable $\mathrm{UO}_{2}$ and to increase the nitrogen potential ${ }^{66}$ as given by Eq. 4 .

$$
3 \mathrm{UN}+\mathrm{O}_{2} \rightarrow \mathrm{UO}_{2}+\mathrm{II}_{2} \mathrm{~N}_{3}
$$

Excess oxygen results in the release of nitrogen 66 as given by Eq. 5 .

$$
2 \mathrm{U}_{2} \mathrm{~N}_{3}+4 \mathrm{O}_{2} \rightarrow 4 \mathrm{UO}_{2}+3 \mathrm{~N}_{2}
$$

(2) $\mathrm{UO}_{2}$ and $\mathrm{U}_{2} \mathrm{~N}_{3}$ are completely miscible above $1200^{\circ} \mathrm{C}$. A homogeneous oxygen content of 2 to 3 wt \% stabilizes $\mathrm{U}_{2} \mathrm{~N}_{3} 68,77$ (and decreases the nitrogen activity). Decreased nitriding of the cladding occurs when $\mathrm{In}_{2}$ is present in the $\mathrm{U}_{2} \mathrm{~N}_{3}$ pliase. 66

\section{CONCLUSIONS}

Problems of chemical compatibility between cladding alloys and advanced FBR fuels may not be as intense as the corrosion encountered with mixed oxide fuel. The principal problem encountered in the limited number of studies carried out on advanced fuels is the change in the mechanical properties die to carburization or nitriding of the cladding. Compatibility testing needs to be extended to cladding alloys other than type 316 stainless steel and NIMONIC PE-16. In carbide fuel pins, the depth of carburization increases with sodium ( $v s$. gas) bonding. The depth of carburization also increases with increasing sesquicarbide $\left(\mathrm{M}_{2} \mathrm{C}_{3}\right)$ content of the fuel. 


\section{REFERENCES}

1. J. G. Conner and S. W. Porembka, BMI-1900 (1968).

2. 0. Gotzmann and R. W. Ohse, EUR-4892 (1972).

3. E. K. Storms and R. J. Ackermann, IAEA Panel on Thermodynamic Properties of the UC, PuC and (U,Pu)C Systems, Grenoble, France, May 1974.

4. M. Hanson, Constitution of Binary AZZoys, McGraw-Hi11, New York (1958):

5. F. A. Shunk, Second Supplement to Constitution of Binary AlZoys, McGraw-H111, New York (1969).

6. B. R. Hayward, NAA-SR-11450 (1965).

7. F. B. Litton, LA-3799 (1968).

8. 0. Gotzmann and D. Scherl, KFK 1213 (1970).

9. B. T. Bradbury, L. E. Russe11, and M. B. Waldron, ANL-7120, p. 328 (1965).

10. K. Natesan and T. F. Kassner, J. Nucl. Mater. 37, 223 (1970).

11. S. K. Dutta and J. White, Proc. Brit. Ceram. Soc. 7, 177 (1967).

12. M. Mouchnino, CEA-3353 (1967).

13. W. Chubb, Nuc1. Sc1. Eng. 29, 176 (1967).

14. M. Ugajin, I. Takahashi, Y. Suzuki, J. Abe, and M. Kurihara, J. Nucl. Mater. 49, $151(1973 / 74)$.

15. F. Gorle, W. Timmermanns, F. Casteels, J. Vangeel, and M. Brabers, Proc. IAEA Symp. on Thermodynamics of Nuclear Materials, Vienna, September 4-8,1967, P. 481 (1968).

16. A. Delbrassine and M. Coquerelle, Proc. IAEA Symp. on Fuel and Fuel Elements for Fast Reactors, Brussels, July 2-6, 1973, Vo1. 1, p. 247 (1974)'.

17. K. R. Jordan, R. J. Herbst, and R. G. Palm, ANL-7120, p. 301 (1965).

18. R. J. Herbst, Trans. Amer. Nucl. Soc. 9, 17 (1966).

19. C. A. Milet, CEA-R-3656 (1968).

20. 0. Gotzmann and P. Hofmann, Proc. IAEA Symp. on Fuel and Fuel Elements for Fast Reactors, Brussels, July 2-6, 1973, Vol. I, p. 233 (1974).

21. P. Hofmann, EURFNR-1139 (1973).

22. D. J. Hodkin, J. P. Evans, and P. G. Mardon, AERE-R-5173 (1966). 
23. 0. Gotzmann, P. Hofmann, and Y. Sarikaya, EURFNR-1173 (1973).

24. R. B. Snyder, K. Natesan, and T. F. Kassner, J. Nucl. Mater. 50, 259 (1974).

25. N. Lorenzelli and J. P. Marcon, Proc. IAEA Symp. on Behavior and Chemical State of Irradiated Ceramic Fuels, Vienna, August 7-11, 1972, p. 99 (1974).

26. N. Lorenzelli and J. P. Marcon, J. Nucl. Mater. 44, 57 (1972).

27. E. K. Storms, The Refractory Carbides, Academic Press, New York, p. 210 (1967).

28. N. Lorenzel1i, CEA-R-4465 (1973).

29. H. R. Haines and P. E. Potter, Proc. IAEA Symp. on Thermodynamics of Nuclear Materials, Vienna, October 21-25, 1974, in press.

30. M. Tetenbaum and P. D. Hunt, J. Nucl. Mater. 40, 104 (1971).

31. M. Tetenbaum and P. D. Hunt, "Study of the Transformation of Crystals at High Temperatures," International Colloquium of the French National Center for Scientific Research \#205, Odeillo, France, September 27-30, 1971.

32. P. M. French and D. J. Hodkin, PZutonizon 1965, Chapman and Hall, London, p. 697.

33. G. Nishio, H. Watanabe, and J. Shimokawa, Nucl. Eng. and Design 22, 326 (1972).

34. M. H. Rund, IAEA Panel on Thermodynamic Properties of the UC, Yul and (U, $\mathrm{Pu}$ )C Systems, Grenoble, France, May 1974, in revised form, March 1975.

35. W. M. Pardue, V. W. Storhok, R. A. Smith, and D. L. Keller, BMI-1698 $(1961)$.

36. A. A. Strasser and J. H. Kittel, Nuclear Metallurgy 13, 460 (1968).

37. T. W. Latimer, L. A. Neimark, C. E. Johnson, and C. E. Crouthame1, Trans. Amer. Nucl. Soc. 1E, by4 (196y).

38. T. W. Latimer, ANL-7827 (1971).

39. W. Batey, D. M. Donaldson, and M. B. Finlayson, Plutonium 1965, Chapman and Hall, London, p. 888.

40. UNC-5217 (1968).

41. R. Lorenzel1i, P. Delaroche, M. Housseau, and P. Petit, Plutonizm 1970; The Metallurgical Society, AIMMPE, New York, p. 818. 
42. W. R. Jacoby, R. G. Palm, and W. E. Ray, WCAP-3791-3 (1967).

43. B. L. Harbourne, P. J. Levine, T. W. Latimer, and L. A. Neimark, Proc. Conf. Fast Reactor and Fuel Element Technology, New Orleans, 1971, p. 869.

44. GU-5286 (1972).

45. W. Batey, D. M. Donaldson, H. W. Irons, and G. Yates, TRG-1835(D) (1969).

46. J. 0. Barner, LA-4669 (1971).

47. A. Strasser, J. Cihi, W. Sheridan, and V. Storhok, Nuclear Metallurgy 10, $729(1964)$.

48. D. Stahl and A. Strasser, UNC-5198 (1968).

49. GU-5279 (1971).

50. J. C. Clifford, LA-4951 (1973).

51. R. Powers and A. Strasser, UNC-5229 (1968).

52. T. W. Latimer, J. 0. Barner, J. F. Kerrisk, and J. L. Green, Trans . Amer. Nucl. Soc. 19, 91 (1974).

53. D. J. Hodkin and P. G. Mardon, AERE-R-5276 (1966).

54. A. Strasser, UNC-5134, Vo1. I (1965).

55. D. Stahl, UNC-5074 (1963).

56. W. Batey, K. Bolton, D. M. Donaldson, and G. Yates, Carbides in Nuclear Energy, Macmillan, London, Vo1. I, p. 392 (1963).

57. D. Stahl and A. Strasser, Carbides in Nuclear Energy, Marmillan, Lundon, Vol. L, p. 373 (1963).

58. T. W. Latimer, Los Alamos Scientific Laboratory, New Mexico, private communication.

59. J. D. B. Lambert, D. L. Johnson, J. R. Honekamp, and L. A. Neimark, Trans. Amer. Nucl. Soc. 19, 90 (1974).

60. H. Holleck, Proc. IAEA Symp. on Thermodynamiss of Nuclear Materiale, Vienna, October 21-25, 1974, in press.

61. B. J: Thamer, LA-3646 (1967).

62. W. M. Pardue, V. W. Storhok, and R. A. Smith, Plutonium 1965, Chapman and Ha11, London, p. 721.

63. D. L. Keller, BMI-1837 (1968). 
64. D. L. Keller, BMI-1845 (1968).

65. W. M. Pardue, A. A. Bauer, and D. L. Keller, Proc. Inter. Symp. on Ceramic Nuclear Fuels, American Ceramic Soclety, p. 166 (1969):

66. J. C. Hebeisen, D. P. Moak, and W. H. Pfeifer, BMI-1895 (1971).

67. A. A. Bauer, Reactor Technology 15, 87 (1972).

68. D. L. Keller, BMI-1868 (1969).

69. M. Allbutt and A. R. Junkison, AERE-R-5466 (1967).

70. S. Kaț, J. Nuc1. Mater. 6, 172 (1962).

71. ก, T.. Ke11.er, BMI-X-10061 (1963).

72. D, L. KeIler, DMI-K-10092 (1961).

73. D. L. Keller, BMI-1778 (1966).

74. W. M. Pardue, F. A. Rough, and R. A. Smith, Nuclear Metallurgy 13, 369 (1968).

75. R. A. Wullaert, J. E. Gates, and J. Bug1, Bul1. Amer. Ceram. Soc. 43, 836 (1964).

76. J. C. Hebeisen, D. P. Moak, and J. H. Saling, Trans, Amer. Nuc1. Soc. 12,595 (1969).

77. J. M. Leitnaker, K. L. Beacty, and K. E. 3pear, Trans. Amer. Nucl. Sor., 12,86 (1969). 